\title{
Should denialism of mental illness and its treatment be included among conspiracy theories?
}

\author{
Konstantinos N. Fountoulakis ${ }^{1}$ (D)
}

Published online: 3 May 2021

๑) Springer-Verlag GmbH Germany, part of Springer Nature 2021

Dear editor,

For decades, there is a strong current in society concerning the denial of the existence of mental illness as a medical disorder and the need for specific treatment of patients according to the biomedical model. This denial persists in spite of research developments, and new waves of attacks against mainstream Psychiatry emerge from time to time.

The current short viewpoint will not address the issue of mental illness per se. The author considers it solved; mental illness is real and mental patients are in need of some kind of biomedical type treatment, including targeted and evidencebased psychotherapy. It will only deal with the characteristics of those viewpoints that reject the above claim and compare these characteristics with those of medical conspiracy theories.

This oppositional attitude is not unique or isolated to Psychiatry alone. Several fields of medicine experience similar attacks and disputes, including the anti-vaccine movement, AIDS denialism, and more recently conspiracy theories pertaining to the COVID-19 outbreak. Interestingly, the COVID-19 pandemic seems to relate to the emergence of mental disorders as a direct neurobiological consequence of the virus infection [1], as a secondary psychological reaction to suffering [2], while the treatment and care of mental disorders are further complicated during the pandemic because of restrictions in movements which led to the proliferation of online services [3]. However, more difficult to cope with are the emergence of new aspects of stigma and the flourishing of conspiracism. The big difference is that the scientific community is fast in recognizing these medical 'disputes'

Konstantinos N. Fountoulakis

kfount@med.auth.gr

1 3rd Department of Psychiatry, Faculty of Medicine, School of Health Sciences, Aristotle University of Thessaloniki, 6, Odysseos str (1st Parodos Ampelonon str.), 55535 Pylaia, Thessaloniki, Greece as 'conspiracy theories' but concerning the attacks on Psychiatry the prevailing attitude is that they are more or less scientifically legitimate and culturally sanctioned. The question which arises is whether the discussions concerning the existence of mental disorder and the efficacy of psychiatric treatment constitute today a form of 'denialism' and they have similar qualities with medical conspiracy theories.

The earliest rejection of the concept of mental illness could be found in the work of Thomas Szasz and his 1961 book 'The Myth of Mental Illness'. In this book, he argued that the very concept of mental illness was a logical absurdity defined exclusively on the basis of value (ethics, morality, legal issues, and social norm) and went even further, placed Psychiatry in the company of alchemy and astrology and defined it as pseudoscience. In agreement with Szasz, Michel Foucault considered psychiatric treatment to be essentially evil. This was because according to this theory, the concept of mental illness is considered to be the product of a 'biopower environment' in the frame of the technocratic-economic organization of the whole society, and with 'patients' waiting to be restored and to be optimized as a biological capital with the use of medicine. According to both Szasz and Foucault, Psychiatry is part of the disciplinary system, and psychiatrists together with other mental health professionals are simply instruments of public order enforcement. Jean-Paul Sartre, the leading figure of existential philosophy, in his foreword to the best-seller book 'The divided self' by Ronald David Laing argued that 'mental illness is the revolt that the free organism in its total entity invents to live in an unbearable situation'. Unfortunately, these views enjoy wide acceptance in the world of arts and literature, making them culturally sanctioned. Such approaches are very difficult to tackle because they a-priori reject the scientific way; they do not engage in discussions that follow the rules of science, or even at least those of analytical philosophy.

Recently, a new wave of disputing emerged, using the 'evidence based approach' as a tool, but by violating its core principles. The most celebrated such argument was that of 
Table 1 Comparison of the characteristics of medical denial conspiracy theories and mental illness denial

\begin{tabular}{|c|c|c|c|c|c|c|}
\hline & $\begin{array}{l}\text { HIV/AIDS } \\
\text { denial }\end{array}$ & Anti-vax & $\begin{array}{l}\text { Climate change } \\
\text { denial }\end{array}$ & COVID-19 & $\begin{array}{l}\text { Mental illness } \\
\text { denial }\end{array}$ & $\begin{array}{l}\text { Holo- } \\
\text { caust } \\
\text { denial }\end{array}$ \\
\hline There is no real disease/problem & & & $\mathrm{x}$ & $\mathrm{x}$ & $\mathrm{x}$ & $\mathrm{x}$ \\
\hline Different cause of the disease/problem & $\mathrm{x}$ & & $\mathrm{x}$ & & $\mathrm{x}$ & $\mathrm{x}$ \\
\hline Scientists are corrupt & & $\mathrm{x}$ & $\mathrm{x}$ & & $\mathrm{x}$ & \\
\hline Treatment is useless & $\mathrm{x}$ & $\mathrm{x}$ & & & $\mathrm{x}$ & \\
\hline Magnification of scientific disagreement & & $\mathrm{x}$ & $\mathrm{x}$ & $\mathrm{x}$ & $\mathrm{x}$ & \\
\hline Treatment is harmful (exaggerate adverse events) & $\mathrm{x}$ & $\mathrm{x}$ & & & $\mathrm{x}$ & \\
\hline Treatment causes the disease & $\mathrm{x}$ & & & & $\mathrm{x}$ & \\
\hline It is an oppression/civil rights issue & $\mathrm{x}$ & $\mathrm{x}$ & $\mathrm{x}$ & $\mathrm{x}$ & $\mathrm{x}$ & \\
\hline Cherry-picking of data & $\mathrm{x}$ & $\mathrm{x}$ & $\mathrm{x}$ & $\mathrm{x}$ & $\mathrm{x}$ & $\mathrm{x}$ \\
\hline Disease/problem is human-made & $\mathrm{x}$ & $\mathrm{x}$ & & $\mathrm{x}$ & $\mathrm{x}$ & \\
\hline Specific agencies involved & $\mathrm{x}$ & $\mathrm{x}$ & & $\mathrm{x}$ & $\mathrm{x}$ & $\mathrm{x}$ \\
\hline Reflects an organized criminal activity & $\mathrm{x}$ & $\mathrm{x}$ & & & $\mathrm{x}$ & \\
\hline Emotionally loaded debates & $\mathrm{x}$ & $\mathrm{x}$ & $\mathrm{x}$ & $\mathrm{x}$ & $\mathrm{x}$ & $\mathrm{x}$ \\
\hline Strong opinion by lay persons & & $\mathrm{x}$ & $\mathrm{x}$ & $\mathrm{x}$ & $\mathrm{x}$ & $\mathrm{x}$ \\
\hline Correlates with other theories & $\mathrm{x}$ & $\mathrm{x}$ & $\mathrm{x}$ & $\mathrm{x}$ & $\mathrm{x}$ & $\mathrm{x}$ \\
\hline Religious component & & & & $\mathrm{x}$ & $\mathrm{x}$ & $\mathrm{x}$ \\
\hline Racial component & $\mathrm{x}$ & $\mathrm{x}$ & & $\mathrm{x}$ & & $\mathrm{x}$ \\
\hline
\end{tabular}

Holocaust denial is included for comparison reasons with conspiracism in general. Mental illness denial definitely has the qualities to be considered a conspiracy theory

Irwin Kirsch, which after his 2008 meta-analysis suggested that antidepressants are essentially useless. Kirsch went on and wrote a book under the title 'The Emperor's New Drugs: Exploding the Antidepressant Myth' [4] and accused the FDA of conspiracy [5]. The view that antidepressants do not work was also promoted by Marcia Angell who was former Editor in Chief of the NEJM and author of a number of antipsychiatric articles and of a book accusing the pharma industry of deceiving the public [6].

Recently, similar reservations on the usefulness of antipsychotics emerged and many authors insist on the uselessness and possible harmful effects even of the short-term initial treatment [7]. Several authors tend to attribute the unfavorable outcome of schizophrenia to treatment with antipsychotics, cannabis use, diabetes, and hypertension $[8$, 9].

The attack on antidepressants was relaunched by the Danish physician and Board member of the Cochrane, Peter Gotzsche who suggested that there is more or less a conspiracy by the 'big pharma' which he labeled 'organized crime' [10] and by medical journals to hide the truth concerning antidepressants. He even involved the Cochrane in these accusations and was eventually expelled from it in 2018. He argued that psychiatric medications are a leading cause of death and the truth is hidden from the public in an organized way. The webpage 'Mad in America' was the main vehicle to disseminate these views and it even hosted articles rejected by scientific journals. In an unusual twist of usual practice, 'Mad in America' published a scientific article rejected by a psychiatric journal, and a psychiatric journal published an article by Robert Whitaker, the editor of 'Mad in America'.

Finally, as with all conspiracy and denialist theories, the metaphysical-religious component could not be absent, and it is represented mainly by the Church of Scientology.

The characteristics of the denial of mental illness and its medication treatment are summarized in Table 1, also in comparison to how these characteristics appear in other medical denial theories. It is more than evident that mental illness denial accumulates many more conspiracy theories characteristics than vaccines or COVID-19 do, and probably only because of their deep and pervasive roots in the lay culture it is that mental illness and treatment denial is not yet included in the list of conspiracy theories. However, this might not be simply a matter of culturally sanctioned ideas and worldviews; it could well be the effect of a pervasive and resilient stigmatizing attitude from the side of intellectuals towards mental patients. The reason is that the mere existence of mental illness destroys the concept of human freedom as articulated in existentialism and related philosophy.

\section{Declarations}

Conflict of interest KNF has no conflict of interest since January 2020. In the past has received grants and served as consultant, advisor or 
CME speaker for the following entities: AstraZeneca, Bristol-Myers Squibb, Eli Lilly, Ferrer, Gedeon Richter, Janssen, Lundbeck, Otsuka, Pfizer, the Pfizer Foundation, Sanofi-Aventis, Servier, Shire, and others.

\section{References}

1. Jung M, Rujescu D (2020) Immune cell puzzle COVID-19: how do SARS-CoV infections contribute to psychiatric diseases? Eur Arch Psychiatry ClinNeurosci 270:643-644

2. Stefana A, Youngstrom EA, Hopwood CJ, Dakanalis A (2020) The COVID-19 pandemic brings a second wave of social isolation and disrupted services. Eur Arch Psychiatry ClinNeurosci 270:785-786

3. Hu N, Pan S, Sun J, Wang Z, Mao H (2020) Mental health treatment online during the COVID-19 outbreak. Eur Arch Psychiatry ClinNeurosci 270:783-784
4. Kirsch I (2009) The emperor's new drugs: exploding the antidepressant myth. The Bodley Head, London

5. Kirsch I (2009) Antidepressants and the placebo response. EpidemiolPsichiatrSoc 18:318-322

6. Angell M (2004) The truth about the drug companies: how they deceive us and what to do about it. Random House

7. Moncrieff J (2006) Does antipsychotic withdrawal provoke psychosis? Review of the literature on rapid onset psychosis (supersensitivity psychosis) and withdrawal-related relapse. ActaPsychiatrScand 114:3-13

8. Murray RM (2017) Mistakes I have made in my research career. Schizophr Bull 43:253-256

9. Zipursky RB, Reilly TJ, Murray RM (2013) The myth of schizophrenia as a progressive brain disease. Schizophr Bull 39:1363-1372

10. Gotzsche P (2013) Deadly medicines and organised crime: how big pharma has corrupted healthcare. CRC Press 